\title{
Vitamin D Levels in the Evaluation of Children with Asthma
}

\author{
Linda Linday ${ }^{1}$ \\ ${ }^{1}$ Icahn School of Medicine at Mount Sinai
}

October 29, 2020

\begin{abstract}
A vitamin D level should be included in the initial evaluation of children with asthma.

Pediatric Pulmonology-C
\end{abstract}

Vitamin D Levels in the Evaluation of Children with Asthma

In their recent JAMA paper entitled "Effect of Vitamin $\mathrm{D}_{3}$ Supplementation on Severe Asthma Exacerbations in Children With Asthma and Low Vitamin D Levels," Forno et al. ${ }^{1}$ reported that oral supplementation with vitamin $\mathrm{D}_{3}$, in a dose of 4000 International Units per day, did not significantly improve the time to a severe asthmatic exacerbation when compared to placebo, as assessed in this double-blind, prospective study.

However, per their Figure 1, 43 of 376 Forno's subjects (11.4\%) were excluded for a vitamin D level less than $14 \mathrm{ng} / \mathrm{mL}$. In addition, these investigators reported that $23 \%$ of their participants had vitamin D levels less than $20 \mathrm{ng} / \mathrm{mL}$ at the baseline visit.

The Global Consensus Recommendations ${ }^{2}$ and the American Academy of Pediatrics ${ }^{3,4}$ state that a serum $25 \mathrm{OHD}$ level of [?] $20 \mathrm{ng} / \mathrm{mL}$ should be considered sufficient for bone health in children. Thus, $23 \%$ of Forno's participants had 25OHD levels that were insufficient for pediatric bone health at the baseline visit.

Commercial assays for $25 \mathrm{OHD}$ are readily available, as are inexpensive dietary supplements with oral vitamin D. Given the above findings, a serum 25OHD level should be included in the initial evaluation of children with asthma, with subsequent correction of insufficient levels to a $25 \mathrm{OHD}$ level of at least $20 \mathrm{ng} / \mathrm{mL}$, as part of the appropriate pediatric care of these children.

1. Forno E, Bacharier LB, Phipatanakul W, et al. Effect of Vitamin D3 Supplementation on Severe Asthma Exacerbations in Children With Asthma and Low Vitamin D Levels: The VDKA Randomized Clinical Trial.JAMA. 2020;324(8):752-760.

2. Munns CF, Shaw N, Kiely M, et al. Global Consensus Recommendations on Prevention and Management of Nutritional Rickets. The Journal of Clinical Endocrinology \& Metabolism. 2016;101(2):394-415.

3. Wagner CL, Greer FR. Prevention of rickets and vitamin D deficiency in infants, children, and adolescents. Pediatrics.2008;122(5):1142-1152.

4. Golden NH, Abrams SA. Optimizing Bone Health in Children and Adolescents. Pediatrics. 2014;134(4):e1229-e1243.

Words: 321

Linda A. Linday, MD

Assistant Clinical Professor of Pediatrics 
Icahn School of Medicine at Mount Sinai

E-mail: lal14@caa.columbia.edu 